\title{
The influence of healthcare factors on medical waste man- agement in Serbian hospital facilities
}

\section{Faktori zdravstvene zaštite koji utiču na upravljanje medicinskim otpadom u bolničkim ustanovama u Srbiji}

\author{
Verica Jovanovic ${ }^{1}$,Dragomir Jovanovic ${ }^{2}$, Branislava Matic ${ }^{1}$ \\ Nela Djonovic ${ }^{3}$ \\ 1. Institute of Public Health of Serbia, Belgrade, Serbia \\ . Clinic for gynecology and obstetrics, GAK "Narodni front”, Belgrade, Sebia \\ 3. Faculty of Medical Sciencies, University of Kragujevac, Kragujevac, Serbia \\ RECEIVED 21.09.2016. \\ ACCEPTED 02.12 .2016
}

\section{ABSTRACT}

Objective. The aim of the study was to analyze different factors of hospital healthcare that have an influence on the MWM.

Method. The research was carried out as a cross-sectional study of a representative secondary and tertiary level hospital sample in the public domain, in November 2014. A special questionnaire was developed for the survey, based on the UN-WHO guidelines for the rapid assessment of medical waste management in a hospital setting.

Results. By using the Mann Whitney U-test, a statistically significant difference was found between secondary level of healthcare $(M D=23.393, N=43)$ and tertiary level hospitals (MD=40000, $N=17)(U=198, p=0.006)$ on the grounds of quantities of medical waste generated. Aforementioned difference was found with regards to the level of healthcare, when it comes to medical waste generation $(U=198, p=0.006)$, pathological waste generation $(U=132, p=0.000)$, and pharmaceutical waste generation $(U=221, p=0.018)$ in a hospital setting. Tertiary healthcare level hospitals produce, statistically, a significantly bigger quantity of hazardous medical waste in all waste categories $(U=198, p=0,006)$.

Conclusion. There is a direct and strong correlation between the total number of beds, hospital days, healthcare services provided and staff members trained in the area of medical waste management, identified as the main factors that impact the management of hazardous medical waste.

Key words: medical waste disposal; health services; organization and administration

\author{
Verica Jovanović ${ }^{1}$,Dragomir Jovanović ${ }^{2}$, Branislava Matić ${ }^{1}$ \\ Nela Đonović3 \\ 1. Institut za javno zdravlje Srbije "Dr Milan Jovanović Batut", Beograd \\ 2. Klinika za ginekologiju i akušerstvo, GAK "Narodni front”, Beograd \\ 3. Fakultet medicinskih nauka, Univerzitet u Kragujevcu, Kragujevac \\ PRIMLJEN 21.09.2016 \\ PRIHVAĆEN 02.12 .2016
}

\section{APSTRAKT}

Cilj. Cilj istraživanja je analiza uticaja različitih faktora zdravstvene zaštite na upravljanje medicinskim otpadom.

Metod. Istraživanje je sprovedeno kao studija preseka na reprezentativnom uzorku bolničkih ustanova sekundarne i tercijerne zdravstvene zaštite u mreži državnih zdravstvenih ustanova, u novembru 2014.godine. Za potrebe istraživanja razvijen je i korišćen posebno dizajniran upitnik, sačinjen na osnovu modela upitnika Ujedinjenih nacija i Svetske zdravstvene organizacije za brze procene upravljanja medicinskim otpadom u bolničkim ustanovama.

Rezultati. Korišćenjem Mann Whitney U-testa utvrđena je statistički značajna razlika između ustanova na sekundarnom $(\mathrm{MD}=23.393, \mathrm{~N}=43)$ i tercijernom nivou zdravstvene zaštite $(M D=40000, N=17)(U=198, p=0.006)$ u vezi generisanih količina medicinskog otpada. Ustanove tercijernog nivoa zdravstvene zaštite generišu statistički značajno veće količine opasnog medicinskog otpada u svim evidentiranim tokovima otpada $(U=198, p=0,006)$. Statistički značajna razlika je utvrđena u odnosu na nivo zdravstvene zaštite u odnosu na generisanje medicinskog otpada $(U=198, p=0.006)$, patoanatomskog otpada $(\mathrm{U}=132, \mathrm{p}=0.000)$, i farmaceutskog otpada $(\mathrm{U}=221, \mathrm{p}=0.018) \mathrm{u}$ bolničkim ustanovama. Ustanove tercijerne zdravstvene zaštite proizvode statistički značajno veće količine opsanog medicinskog otpada u svim analiziranim tokovima $(\mathrm{U}=198, \mathrm{p}=0,006)$.

Zaključak. Utvrđena je direktna i jaka povezanost između ukupnog broja bolničkih kreveta, ostvarenih bolničkih dana, kao i broja obučenih radnika u oblasti upravljanja medicinskim otpadom, koji su i izdvojeni kao glavni faktori zdravstvene zaštite koji utiču na upravljanje opasnim medicinskim otpadom.

Ključne reči: uklanjanje medicinskog otpada; zdravstvene ustanove; organizacija i administracija. 


\section{INTRODUCTION}

Medical waste is generated in the course of providing healthcare services in healthcare institutions. Healthcare facilities are obliged to classify the waste they generate and to segregate it into different categories or streams.

The aim of this study was to analyze different factors of hospital healthcare that are influencing medical waste management in hospitals.

Specific objectives of the study were to assess correlations between said factors and medical waste management particularly focused on hazardous medical waste streams.

The Law on Waste Management of the Republic of Serbia defines hazardous waste streams generated in healthcare institutions: "infectious waste, cytotoxic waste, pathological waste, chemical waste, toxic waste, pharmaceutical waste, sharps and other hazardous waste". The Waste Catalogue of the Republic of Serbia, which is developed based on the European Waste Catalogue, differentiates between the said types of medical waste as well. In the catalogue, each type of waste is identified by a six-digit code, or index number. All codes pertaining to medical waste in human medicine start with $1801 .^{1,2}$

Since 2009, innovations in medical waste management have been introduced into all healthcare institutions in Serbia including hospitals. Hospitals are obliged to establish safe system of hazardous waste management.

According to WHO, medical waste is classified as nonrisk waste stream or general medical waste, which is comparable to household waste, and as hazardous medical waste, which has the potential to pose a variety of health risks. ${ }^{3-7}$ Hazardous medical waste may include infectious waste, pathological waste, sharps, pharmaceutical waste, chemical waste, waste with a high heavy metal content, pressurized containers and radioactive waste. ${ }^{8-9}$

In the Republic of Serbia, hospitals are equipped by autoclaves for the sterilization of the infectious medical waste, which was installed in state-owned hospitals in the period from 2007 to 2009, during the implementation of the Ministry of Health's projects, funded by the European Union: "Technical Assistance for Healthcare Waste Management" ("04SER01/08/001 Project (CRIS contract number 162832)) and "Technical Assistance for Healthcare Waste Treatment in Serbia" project (O8SER/31/12/00). However, there is still lack of the capacity for the management of a pharmaceutical, cytostatic and chemical waste from hospitals in Serbia, and these streams are handed over to private hazardous waste operators. Pathological waste is mostly buried. Important factors of healthcare are the country's economical status, the type of hospital, its bed capacity, location, etc. - dictate the amount of hazardous waste generated during provision of healthcare services. ${ }^{10}$ Segregation and labeling of wastes at the source may help in identifying the proper handling and treatment procedures and technologies. ${ }^{11-14}$

\section{METHODS}

The survey was conducted as a cross-sectional study at the representative sample of hospitals in November 2014, using a questionnaire developed for the research based on guideline of the World Healthcare Organisation (UNWHO HCWM Rapid Assessment Tool) $)^{15}$

Ethical approval to conduct the study was provided from the ethical committee of the Institute of Public Health of Serbia "Dr Milan Jovanovic Batut" (letter number IPHRS $3370 / 1)$.

The research sample consists of 60 secondary and tertiary level hospitals, selected at random. The sample size was defined based on pilot studies conducted in Serbia during the implementation of the EU funded project "Technical Assistance for Healthcare Waste Management" ("04SER01/08/001 Project (CRIS contract number 162832)). Based on the conducted pilot studies (for the level of correlation of 0.35 , the power of the study $1-\beta=0.8$, and the level of $\alpha=0.05$ ) a sufficient number of observation units is 60 .

The data were supplemented with data from the database of the Institute for Public Health of Serbia "Dr Milan Jovanović Batut" concerning medical waste management. Data were collected directly from hospitals, at annual level, as part of regular reporting obligation of healthcare facilities equipped by autoclaves, to the Institute "Batut".

Level of health care (secondary and tertiary), number of beds per institution, number of outpatient and in-patient days and number of staff trained in healthcare waste management were identified as independent variables for the survey.

Quantities of generated and segregated infectious, pharmaceutical and pathological waste as well as municipal waste were analyzed as dependant variables. During the course of the survey the data has been collected, analyzed and reanalyzed and the most significant correlations between hospital healthcare service provision and the management of hazardous waste have been identified as such.

Hospitals were analyzed particularly with regards to the quantities of infectious healthcare waste, as the most commonly segregated type of hazardous medical waste in hospitals, as well as with regards to the quantities of pharmaceutical and pathological waste generated in the course of healthcare provision including oncology healthcare. 


\section{Statistical methodology}

All statistical analyses were performed using IBM SPSS Statistics for Windows Software Version 20.0. Results were presented as mean and standard deviation (mean \pm standard deviation). Mann-Whitney U-test was used to compare the two groups. All p-values lower than 0.05 were considered statistically significant.

The numerical data collected from the selected hospitals was compiled using Microsoft Excel software. Data concerning medical waste management (owning autoclaves, having waste management plans approved) were encoded to a binary system ( 1 and 0 ), where 1 implies the presence of a particular item and 0 the absence of such item/category. The encoded items were summed up to provide the frequencies and the percentage was calculated using MS Excel and SPSS software.

\section{RESULTS}

This study investigated medical waste management in hospitals, in four regions in Serbia, at two levels of healthcare services provision - secondary level (General Hospitals) and tertiary level (Institutes, Clinical Centers and Clinical Hospital Centers) (Table 1).

Table 1. Distribution of hospitals per region in Serbia

\begin{tabular}{|l|c|c|}
\hline Region & Frequency & Percent \\
\hline & & \\
\hline Vojvodina & 14 & 23.30 \\
\hline Belgrade & 12 & 20.00 \\
\hline $\begin{array}{l}\text { Šumadija and Western } \\
\text { Serbia }\end{array}$ & 16 & 26.70 \\
\hline Southern and Eastern Serbia & 18 & 30.00 \\
\hline Total & 60 & 100.00 \\
\hline Type of hospital & & \\
\hline General hospital & 40 & 66.70 \\
\hline Special hospital 1 & 2 & 3.30 \\
\hline Special hospital 2 & 1 & 1.70 \\
\hline Institute & 7 & 11.70 \\
\hline Clinics & 2 & 3.30 \\
\hline Clinical Hospital Centre & 4 & 6.70 \\
\hline Clinical Center & 4 & 6.70 \\
\hline Total & 60 & 100.00 \\
\hline Referrals & 60 & 100.00 \\
\hline Secondary level & & 71.70 \\
\hline Tertiary level & & 28.30 \\
\hline Total & & \\
\hline & & \\
\hline
\end{tabular}
waste generated

\begin{tabular}{|c|c|c|c|c|c|c|c|}
\hline $\begin{array}{l}\frac{\text { ฯ }}{0} \\
\frac{0}{\frac{0}{\frac{1}{0}}} \\
\frac{\pi}{>}\end{array}$ & Referrals & $N$ & $\begin{array}{l}\text { Mean } \\
\text { Rank }\end{array}$ & Median & $\begin{array}{l}\text { Mann- } \\
\text { Whit- } \\
\text { ney U }\end{array}$ & Z & 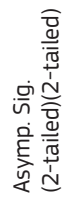 \\
\hline \multirow{2}{*}{ 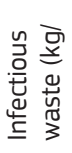 } & $\begin{array}{l}\text { Second- } \\
\text { ary level }\end{array}$ & 43 & 26.58 & $22,447.00$ & \multirow{2}{*}{197.00} & \multirow{2}{*}{$\begin{array}{c}- \\
2.764\end{array}$} & \multirow{2}{*}{$\begin{array}{l}\varphi \\
\circ \\
\circ \\
\circ\end{array}$} \\
\hline & $\begin{array}{l}\text { Tertiary } \\
\text { level }\end{array}$ & 17 & 40.41 & $37,811.90$ & & & \\
\hline \multirow{2}{*}{ 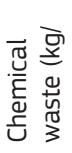 } & $\begin{array}{l}\text { Second- } \\
\text { ary level }\end{array}$ & 43 & 28.30 & 166.46 & \multirow{2}{*}{271.00} & \multirow{2}{*}{$\begin{array}{c}- \\
1.550\end{array}$} & \multirow{2}{*}{$\begin{array}{l}\stackrel{-}{1} \\
\stackrel{-}{0}\end{array}$} \\
\hline & $\begin{array}{l}\text { Tertiary } \\
\text { level }\end{array}$ & 17 & 36.06 & 224.22 & & & \\
\hline \multirow{2}{*}{ 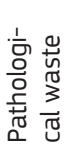 } & $\begin{array}{l}\text { Second- } \\
\text { ary level }\end{array}$ & 43 & 25.07 & 371.76 & \multirow{2}{*}{132.00} & \multirow{2}{*}{$\begin{array}{c}- \\
3.831\end{array}$} & \multirow{2}{*}{$\begin{array}{l}8 \\
\circ \\
\circ\end{array}$} \\
\hline & $\begin{array}{l}\text { Tertiary } \\
\text { level }\end{array}$ & 17 & 44.24 & $1,024.33$ & & & \\
\hline \multirow{2}{*}{ 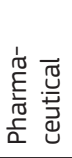 } & $\begin{array}{l}\text { Second- } \\
\text { ary level }\end{array}$ & 43 & 27.14 & 65.00 & \multirow{2}{*}{221.00} & \multirow{2}{*}{$\begin{array}{c}- \\
2.372\end{array}$} & \multirow{2}{*}{$\begin{array}{l}\infty \\
\stackrel{-1}{\circ} \\
0 \\
0\end{array}$} \\
\hline & $\begin{array}{l}\text { Tertiary } \\
\text { level }\end{array}$ & 17 & 39.00 & 89.00 & & & \\
\hline \multirow{2}{*}{ 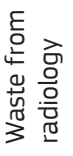 } & $\begin{array}{l}\text { Second- } \\
\text { ary level }\end{array}$ & 43 & 27.67 & 308.00 & \multirow{2}{*}{244.00} & \multirow{2}{*}{$\begin{array}{c}- \\
1.994\end{array}$} & \multirow{2}{*}{ 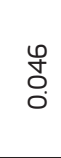 } \\
\hline & $\begin{array}{l}\text { Tertiary } \\
\text { level }\end{array}$ & 17 & 37.65 & 456.00 & & & \\
\hline \multirow{2}{*}{ 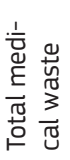 } & $\begin{array}{l}\text { Second- } \\
\text { ary level }\end{array}$ & 43 & 26.60 & $23,393.56$ & \multirow{2}{*}{198.00} & \multirow{2}{*}{$\begin{array}{c}- \\
2.748\end{array}$} & \multirow{2}{*}{ 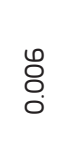 } \\
\hline & $\begin{array}{l}\text { Tertiary } \\
\text { level }\end{array}$ & 17 & 40.35 & $40,001.02$ & & & \\
\hline \multirow{2}{*}{ 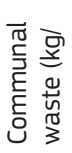 } & $\begin{array}{l}\text { Second- } \\
\text { ary level }\end{array}$ & 43 & 27.12 & $85,000.00$ & \multirow{2}{*}{220.00} & \multirow{2}{*}{$\begin{array}{c}- \\
2.388\end{array}$} & \multirow{2}{*}{$\begin{array}{l}\text { Na } \\
\text { ○̣ } \\
0\end{array}$} \\
\hline & $\begin{array}{l}\text { Tertiary } \\
\text { level }\end{array}$ & 17 & 39.06 & $127,000.00$ & & & \\
\hline
\end{tabular}

By using Mann Whitney U-test statistically significant difference was found between secondary level of healthcare $(\mathrm{MD}=23.393, \mathrm{~N}=43)$ and tertiary level hospitals $(\mathrm{MD}=40$ $000, \mathrm{~N}=17)(\mathrm{U}=198, \mathrm{p}=0.006)$ concerning generated quantities of medical waste.

As for the generated quantities of medical waste, the average annual waste generation per institution at secondary healthcare level amounted to $29,606.71 \mathrm{~kg}$ and at tertiary healthcare level amounted to $73,419.49 \mathrm{~kg}$. The hospitals in large municipalities and at tertiary level of healthcare gener- 
ated larger quantities than those situated in locations covering smaller populations of inhabitants, and thus healthcare services users (Table 3 ). In addition, statistical testing revealed a high statistical significance between the type of hospital and generation of pharmaceutical waste $(\mathrm{x} 2=14.3$, Df=5, p=0.14) (Table 3).

Table 3. Average quantity of medical waste generated, by regions and type of hospital

\begin{tabular}{|c|c|c|c|c|}
\hline Region & Type of hospital & $\begin{array}{l}\text { Fre- }^{-} \\
\text {quency }\end{array}$ & Percent & $\begin{array}{l}\text { Mean Medi- } \\
\text { cal Waste } \\
\text { generation } \\
\text { kg/year }\end{array}$ \\
\hline \multirow{5}{*}{ Vojvodina } & $\begin{array}{l}\text { General hos- } \\
\text { pital }\end{array}$ & 9 & 64.29 & $39,057.57$ \\
\hline & Special hospital & 1 & 7.14 & $13,415.27$ \\
\hline & Institute & 3 & 21.43 & $27,346.69$ \\
\hline & Clinical Centre & 1 & 7.14 & $131,554.84$ \\
\hline & Total & 14 & 100.00 & \\
\hline \multirow{6}{*}{ Belgrade } & Special hospital & 1 & 8.33 & $11,342.88$ \\
\hline & Institute & 4 & 33.33 & $35,375.43$ \\
\hline & Clinics & 2 & 16.67 & $27,406.20$ \\
\hline & $\begin{array}{l}\text { Clinical Hospital } \\
\text { Centre }\end{array}$ & 4 & 33.33 & $49,265.82$ \\
\hline & Clinical Centre & 1 & 8.33 & $396,381.64$ \\
\hline & Total & 12 & 100.00 & \\
\hline \multirow{3}{*}{$\begin{array}{l}\text { Šumadija } \\
\text { and Western } \\
\text { Serbia }\end{array}$} & $\begin{array}{l}\text { General hos- } \\
\text { pital }\end{array}$ & 15 & 93.75 & $35,064.48$ \\
\hline & Clinical Centre & 1 & 6.25 & $100,726.92$ \\
\hline & Total & 16 & 100.00 & \\
\hline \multirow{4}{*}{$\begin{array}{l}\text { Southern } \\
\text { and Eastern } \\
\text { Serbia }\end{array}$} & $\begin{array}{l}\text { General hos- } \\
\text { pital }\end{array}$ & 16 & 88.89 & $22,403.08$ \\
\hline & Special hospital & 1 & 5.56 & $12,395.92$ \\
\hline & Clinical Centre & 1 & 5.56 & $144,050.49$ \\
\hline & Total & 18 & 100.00 & \\
\hline \multirow{7}{*}{ Total } & $\begin{array}{l}\text { General hos- } \\
\text { pital }\end{array}$ & 40 & 66.67 & $30,898.36$ \\
\hline & Special hospital & 3 & 5.00 & $12,384.69$ \\
\hline & Institute & 7 & 11.67 & $31,934.54$ \\
\hline & Clinics & 2 & 3.33 & $27,406.20$ \\
\hline & $\begin{array}{l}\text { Clinical Hospital } \\
\text { Centre }\end{array}$ & 4 & 6.67 & $49,265.82$ \\
\hline & Clinical Centre & 4 & 6.67 & $193,178.47$ \\
\hline & Total & 60 & 100.00 & \\
\hline
\end{tabular}

In analyzing waste generation in hospitals, municipal waste was identified as the most prevalent waste stream (158 $755 \mathrm{~kg} /$ year).

In terms of medical waste, infectious waste is represented with $96 \%$ in the overall hazardous medical waste sample (total medical waste, $42020 \mathrm{~kg} /$ year) (Graf.1) A larger quantity of infectious waste is generated in tertiary level hospitals.

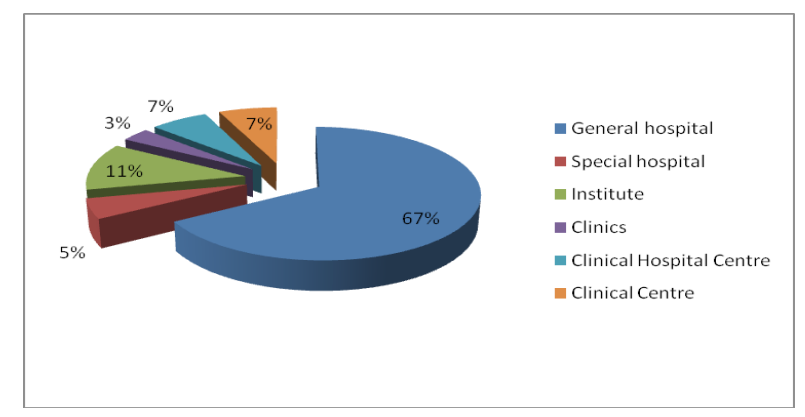

Graf 1. Generation of infectious medical waste per type of hospital

Study showed that, on average, generated 29,606.3 $\mathrm{kg}$ of medical waste per year at the secondary level of health care, while at the tertiary level of health care $73419.49 \mathrm{~kg}$ was generated. The largest share of hazardous medical waste generated has infectious medical waste. The average amount of infectious medical waste is generated annually in $43 \mathrm{sec}-$ ondary healthcare facilities was $28,482.88 \mathrm{~kg}$, while in 17 institutions of tertiary level health care amounted to 70219. $81 \mathrm{~kg}$.

Statistically significant difference was found with regards to the level of healthcare, when it comes to medical waste generation $(U=198, p=0.006)$, pathological waste generation ( $U=132, p=0.000)$, and pharmaceutical waste generation ( $U=221, p=0.018)$ in a healthcare setting. Tertiary healthcare level hospitals produce statistically significantly bigger quantity of hazardous medical waste.

As for the training of the staff for healthcare waste management (HCWM), it was determined that the overall number of trained staff in 2014, using external continual education, amounted to 89 medical staff and auxiliary staff. The largest number of staff trained for medical waste management (MWM) was registered at tertiary level of healthcare institutions ( $94 \%$ of tertiary level institutions).

Still, there are $20 \%$ of hospitals in both levels of healthcare institutions without MWM training (Table 4). 
Table 4. Staff trained for HCWM per level of healthcare and institution

\begin{tabular}{|c|c|c|c|c|}
\hline \multirow{2}{*}{\multicolumn{2}{|c|}{ Referral institution }} & \multicolumn{2}{|c|}{$\begin{array}{l}\text { Trained staff for } \\
\text { HCWM }\end{array}$} & \multirow{3}{*}{$\begin{array}{c}\text { Total } \\
43.00\end{array}$} \\
\hline & & No & Yes & \\
\hline \multirow{3}{*}{$\begin{array}{l}\text { Secondary } \\
\text { level }\end{array}$} & Count & 11.00 & 32.00 & \\
\hline & $\%$ within referral & 25.60 & 74.40 & 100.00 \\
\hline & $\begin{array}{l}\% \text { within trained } \\
\text { staff for HCWM }\end{array}$ & 91.70 & 66.70 & 71.70 \\
\hline \multirow{3}{*}{$\begin{array}{l}\text { Tertiary } \\
\text { level }\end{array}$} & Count & 1.00 & 16.00 & 17.00 \\
\hline & $\%$ within referral & 5.90 & 94.10 & 100.00 \\
\hline & $\begin{array}{l}\% \text { within trained } \\
\text { for HCWM }\end{array}$ & 8.30 & 33.30 & 28.30 \\
\hline \multirow{3}{*}{ Total } & Count & 12.00 & 48.00 & 60.00 \\
\hline & $\%$ within referral & 20.00 & 80.00 & 100.00 \\
\hline & $\begin{array}{l}\% \text { within trained } \\
\text { for HCWM }\end{array}$ & 100.00 & 100.00 & 100.00 \\
\hline
\end{tabular}

However, no statistically significant difference was found per level of healthcare with regards to staff training in MWM. The correlation between the numbers of staff trained in HCWM, number of hospital beds, and quantity of medical waste is presented in Table 5 .

Table 5. The Factors of healthcare service that influencing HCWM

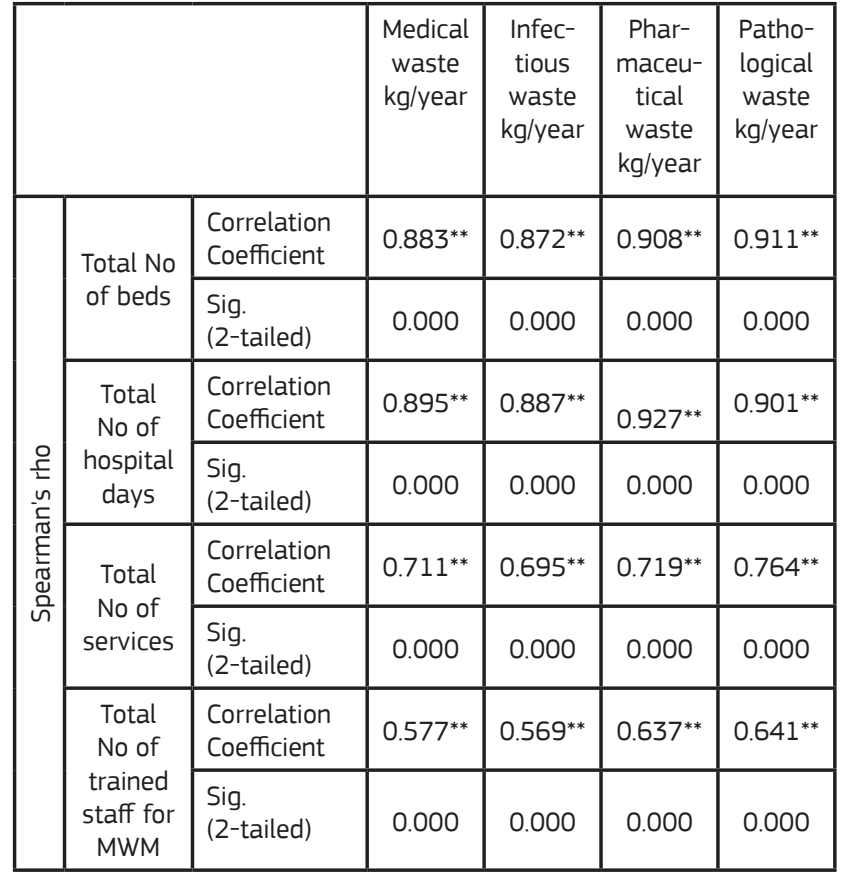

**. Correlation is significant at the 0.01 level (2-tailed). $\mathrm{N}=60$.

\section{DISCUSSION}

Over the past two decades, hazardous medical waste has been identified as one of the major problems that negatively impact both human health and the environment when improperly handled, stored, transported and disposed. For many years, the WHO has advocated that medical waste be regarded as a special waste and it is now commonly acknowledged that certain categories of medical waste are among the most hazardous and potentially dangerous of all waste types generated in communities. ${ }^{16}$

The study has shown that hospitals at tertiary level of healthcare generate larger quantities of medical waste compared to secondary level of healthcare. The quantity of generated medical waste is proportional to the number of inpatient days. Study has shown that the most prevalent type of medical waste in hospitals, classified as hazardous waste is infectious waste (index no. 180103 ) (96\%).

In total, in the 60 observed hospitals, a total of 2483550 $\mathrm{kg}$ infectious waste was generated in 2014, which is $26.7 \%$ of the overall waste generated in the public healthcare sector in Serbia.

There are many technologies available for the treatment of hazardous medical waste worldwide. According to studies that have investigated the treatment of medical waste, about $59-60 \%$ of medical waste materials are treated by incineration, $20-37 \%$ by steam sterilization and $4-5 \%$ by other treatment methods. ${ }^{17-19}$

In Serbia, autoclave technology is only available technology for the treatment of infectious waste. Distribution of autoclaves in healthcare institutions is a direct indicator of the institutions' capacities for independent treatment of infectious healthcare waste.

Research has shown that those institutions that have treatment capacities (autoclaves) available are usually the generators of the largest quantities of infectious medical waste. However, autoclaves are most numerous in secondary level healthcare institutions (71. 7\%).

Larger quantities of segregated hazardous medical waste indicate that the institution practices segregation at the point of generation. In addition, hospitals generating pathological and pharmaceutical waste segregate these types of waste into the hazardous waste streams as well. Research has shown that generation of hazardous medical waste is directly correlated with the number of hospital healthcare services performed in the hospital as well as with number of hospital beds, bed occupancy rate and trained healthcare 
staff for medical waste management. This training for hospital staff has to be in accordance with the legal framework and good practice guidelines on HCWM, abiding the rules set up by WHO's recommendations and implemented in a number of countries, India included.$^{20-23}$

In conclusion analysis of the gathered data concerning medical waste management showed that the practices of medical waste management are in place in all hospitals, at both levels of healthcare provision, secondary and tertiary.

By the quantities of medical waste generated, it can be concluded that the average infectious healthcare waste production, per institution, per year is $28482.88 \mathrm{~kg}$ in hospitals at secondary level and $70219.81 \mathrm{~kg}$ in the tertiary level hospital. The quantities of pharmaceutical waste segregated indicate that medicine usage is not planned as efficiently as it should be, but are also influenced by historical pharmaceutical waste, which is taken from one year into the next, remaining in the possession of the institution due to the lack of technologies for its safe disposal.

Staff training does affect the efficiency of hospital waste management, especially in the categories of segregation and prevention of its generation.

Among the main factors that correlate to the better quality of medical waste management, the particularly important once are: the number of beds, the number of hospital days, the number of outpatient services and the number of trained professionals for HCWM.

The recommendation could be as it follows. Further development and implementation of regulations on hazardous medical waste management in hospitals is of upmost importance for the medical waste management improvement. Development of technical recommendations for the staff dealing with medical waste management is very much needed. Medical waste management is a process, and to ensure its continual progress, adequate continual training - such as continual professional development for the medical and non medical staff working in this field - is necessary.

\section{REFERENCES}

1. Law on Waste Management. Official Gazette of Republic of Serbia, No. 36/09 and 88/10 and 16/16. Belgrade: Official Gazette, 2009.

2. Waste catalogue of the Republic of Serbia. Rulebook on categories, testing and classification of waste. Official Gazette of Republic of Serbia No. 56/10. Belgrade: Official Gazette, 2010.

3. Alves SB, Souza AC, Tipple A, et al. The reality of waste management in primary health care units in Brazil. Waste Manag Res 2014; 32: 40-7.

4. Narendra M, Kousar H, Puttaiah ET. Enumeration of health care waste management at public and private hospital sector of Mysore, Karnataka, India. International Journal of Applied Sciences and Engineering Research 2013; 2: 416-9. doi: 10.6088/ijaser.020400003.

5. Thakur V, Ramesh A. Healthcare waste management research: a structured analysis and review (2005-2014). Waste Manag Res 2015; 33: 855-70.

6. Kumar S, Mazta S, Gupta A.Biomedical solid waste management practices in major public hospitals of Shimla city. Journal of Evolution of Medical and Dental Sciences 2014; 3: 4075-83.

7. Al-Habash M, Al-Zu'bi A. Efficiency and effectiveness of medical waste management performance, health sector and its impact on environment in Jordan - applied study. World Applied Sciences Journal 2012; 19: 880-93.

8. Patil G, Pokhrel K. Biomedical solid waste management in an Indian hospital: a case study. Waste Manag 2005; 25: 592-9.

9. Ghasemi MK, Yusuff R.Advantages and disadvantages of healthcare waste treatment and disposal alternatives: Malaysian Scenario. Pol J Environ Stud 2016; 25: 17-25.

10. Askarian M1, Heidarpoor P, Assadian O. A total quality management approach to healthcare waste management in Namazi Hospital, Iran. Waste Manag 2010; 30: 2321-6.

11. Sarotra $\mathrm{P}$ et al. Health care professional training in biomedical waste management at a tertiary care hospital in India. The Journal of Biomedical Research. 2014; 28(5):1-3, doi: 10.7555/JBR.28.20140060. 
12. Kjellstrom T, Marcado S. Towards action on social determinants for health equity in urban settings. Environ Urban 2008; 20: 551-74.

13. Patwary M, Uddin L, Miah A, Sarker M. Occupational stress and addiction: possible neurobiological elucidation of medical waste related individuals. J Hosp Adm 2013; 2: 71-88.

14. McGaw D, Tennant I, Harding H, Cawich S, Crandon I, Walters CA. Healthcare workers' attitudes to and compliance with infection control guidelines in the operating department at the University Hospital of the West Indies, Jamaica. International Journal of Infection Control 2012; 8: 2-9.

15. Health-care waste management rapid assessment tool. Geneva: World Health organization, 2016. (http:// www.who.int/water_sanitation_health/facilities/waste/hcwmtool/en/)

16. Humbert S, Marshall J, Shaked S, et al. intake fraction for particulate matter: recommendations for life cycle impact assessment. Env Sci Technol 2011; 45: 4808-16.

17. Nichols A, Bennallick M, Manzi S, Grose J, Pahl S, Richardson J. Sustainable healthcare waste management: ethical, legal and practical challenges. CRETE 2012 3rd International Conference on Industrial and Hazardous Waste Management, Chania, Greece, 12-14th Sep, 2012. (http:// www.srcosmos.gr/srcosmos/showpub.aspx?aa=16426)

18. Jovanović J, Krivokapić Z, Ramović S, Perović M. Balances scorecard evaluation model that includes elements of environmental management system using AHP model. Int J Qual Res 2010; 4: 1-8.

19. Hirani DP, Villaitramani KR, Kumbhar SJ. Biomedical waste: an introduction to its management. International Journal of Innovative Research in Advanced Engineering (IJIRAE) 2014; 1: 82-7.

20. Semwal R, Dharmendra. Environmental concern and threat investigation due to malpractices in biomedical waste management: a review. Proceedings of IRF International Conference, 28th February 2016, Goa, India. (http:// iraj.in/up_proc/pdf/206-14567272241-6.pdf).

21. Banerjee S, Mitra S. Radioactive and hospital waste management: a review. International Journal of Latest Trends in Engineering and Technology (IJLTET) 2013; 3 : 275-82.
22. Patil GV, Pokhrel K. Biomedical solid waste management in an Indian hospital: a case study. Waste Manag 2005; 25: 592-9.

23. Chaurasia S, Singh R, Gupta AD, Kumar S. Overview on biomedical waste of district hospital Satna (MP), India. Curr Sci J 2014; 10: 49-53. 